\title{
Kaposi's sarcoma in a patient after renal transplantation
}

\author{
P. J. LITTLE \\ F.R.C.P., F.R.A.C.P. \\ A. Al KHADER \\ M.D., M.R.C.P.
}

\author{
C. F. FARTHING \\ M.B., Ch.B. \\ H. BUNUAN* \\ M.D.
}

\author{
A. HALEEM \\ M. Phil., M.R.C.Path. \\ Riyadh Al Kharj Military Hospital and *King Faisal Specialist Hospital and Research Center, Riyadh, Saudi \\ Arabia
}

\begin{abstract}
Summary
A patient is described who developed the lesion of Kaposi's sarcoma 4 months after receiving a cadaveric renal transplant. Immunosuppression had been achieved using cyclosporin $A$ and prednisolone. The lesions spread from the hands to other areas, but later regressed when the dose of cyclosporin $A$ was reduced to $100 \mathrm{mg}$ daily. The patient remains well with no evidence of rejection 15 months later.
\end{abstract}

KEY WORDS: Kaposi's sarcoma, renal transplantation.

\section{Introduction}

We wish to report the occurrence of Kaposi's sarcoma in a patient who received a renal transplant. His immunosuppressive regime included cyclosporin $A$ and prednisolone.

\section{Case report}

The patient, a 63-year-old Saudi male received a cadaveric donor renal transplant on the 23rd August, 1981. Immunosuppression was commenced with cyclosporin A, $1100 \mathrm{mg}$ daily, and prednisolone, initially $200 \mathrm{mg}$ daily tapering to a maintenance dose of $30 \mathrm{mg}$ daily. Within 2 weeks, his cyclosporin A dose had been reduced to $400 \mathrm{mg}$ daily. However, one week later, he suffered from an acute rejection. This was treated with an increased dose of prednisolone and the cyclosporin A was raised once more to $600 \mathrm{mg}$ daily. His weight at this time was approximately $60 \mathrm{~kg}$. One month later he was receiving prednisolone $15 \mathrm{mg}$ daily; cyclosporin A, $600 \mathrm{mg}$ daily; isoniazid, $300 \mathrm{mg}$ daily and frusemide, $80 \mathrm{mg}$ daily, and he remained on this regime until his return to Saudi Arabia.
On his return to Saudi Arabia, he was found to be fit. His blood pressure was normal and no abnormalities were recorded on physical examination. He was hepatitis antigen $B$ and VDRL negative; serum creatinine was $0.15 \mathrm{mmol} / \mathrm{litre}$; blood urea 17 mmol/litre; haemoglobin $12.9 \mathrm{mg} / \mathrm{dl}$ and the white cell count was $10 \times 10^{9} /$ litre. His creatinine clearance averaged $50 \mathrm{ml} / \mathrm{min}$. Cytomegalovirus (CMV) titre done as part of a viral screen was 128 on 23rd December, 1981; 64 on 29th December, 1981; 16 on 14th January, 1982 and 64 on 7th January, 1982 after immunosuppression was reduced. His renal function remained stable. On 2nd January, for the first time, it was noted that he had developed an infiltrating purplish skin lesion $2 \mathrm{~cm} \times 3 \mathrm{~cm}$ over his left wrist, adjacent to a pre-existing arterio-venous fistula (Fig. 1). Histological examination confirmed the diagnosis of Kaposi's sarcoma (Fig. 2). The dose of cyclosporin A was immediately reduced to $300 \mathrm{mg}$ daily and the prednisolone to $10 \mathrm{mg}$ daily. Even on this reduced dose of cyclosporin $\mathbf{A}$, the tumour continued to grow. New nodular lesions on the left hand and the left ear appeared. Further reduction in cyclosporin A to 100 mg daily and local irradiation with 2500 rads over 10 days resulted in regression of the lesion without evidence of renal rejection. The serum creatinine remained stable at $0.16 \mathrm{mmol} / \mathrm{litre}$.

\section{Discussion}

It is generally agreed that there is an increased risk of malignant disease in immunosuppressed patients following transplantation (Curtis, 1982). Kaposi's sarcoma is a rare tumour in most Western Countries, but is relatively common in Africa (Editorial, 1981). Its incidence in Saudi Arabia is unknown, but other cases are being reported (Akhtar et al., 1982). The 


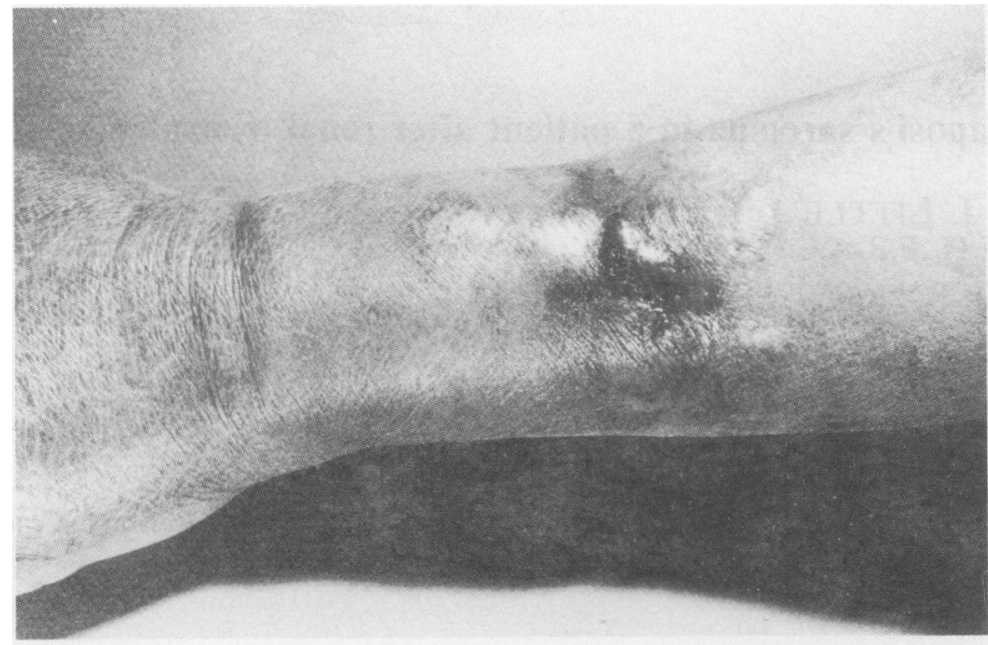

disease is usually more serious in immunocompromised patients and patients receiving steroids. It may respond to cessation of immunosuppressive therapy (Harwood et al., 1979).

It has been suggested that cytomegalovirus infection is associated with Kaposi's sarcoma (Editorial, 1981). This association was not clear in the patient described, but there was a small fall in the CMV titre after presentation. This appears to be the first reported case of Kaposi's sarcoma occurring in a patient immunosuppressed with cyclosporin A. Reduction of the dose of cyclosporin A appears to have produced a satisfactory remission.

\section{References}

Akhtar, M., Bunuan, H., Ashraf, A.M. \& SAL, M. (1982) Kaposi's sarcoma in recipients of renal transplants. King Faisal $\mathrm{N}$ Specialist Hospital Medical Journal, 2, 97.

CuRTIS, J.R. (1982) Cancer and patients with end-stage renal N failure. British Medical Journal, 284, 69.

EDITORIAL (1981) Immunocompromised homosexuals. Lancet, ii, $\omega$ 1325.

Harwood, A.R., Osaba, D., Hofstader, S., Goldstein, M., Cardella, C., Holechek, M., Kunynetz. R. \& Grammarco, R. (1979) Kaposi's sarcoma in recipients of renal transplants. American Journal of Medicine, 67, 759.

(Accepted 8 July 1982) 